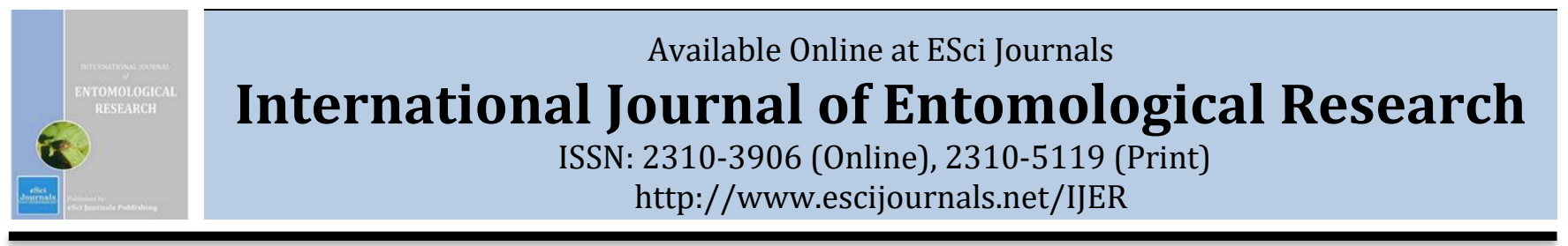

\title{
STATUS OF FALL ARMYWORM (SPODOPTERA FRUGIPERDA), BIOLOGY AND CONTROL MEASURES ON MAIZE CROP IN ETHIOPIA: A REVIEW
}

Fenta Assefa

Department of Plant Sciences, College of Agriculture and Environmental Science, Bahir Dar University, Ethiopia.

\begin{abstract}
A B S T R A C T
Maize (Zea mays) is one of the main and popular cereal crops due to its high value as stable food as well as its stover demand for animal feed and fuel and even for construction purposes. Despite its current productivity is higher than other major cereal crops, the yield productivity is below its potential. These are due to many biotic and abiotic factors that can contribute to its yield potential of productivity to be below the previous productivity. The Fall Army Worm (FAW) is among the major factors contributing to low productivity currently in Ethiopia from its introduction in February 2017. Now it has covered about 52, 962 hectares in 144 districts in six of the major maize-growing regional states, namely Benishangul-Gumuz, Amhara, Tigray, Gambella, Oromia and Southern Nations, Nationalities and Peoples' Region. FAW, a new devastating insect pest is one of serious major problems for agricultural crop production especially under police family (maize) in Ethiopia under warm and humid conditions. This is due to its ability to breed rapidly, to migrate, and to feed on a wide range of host plants and these make it very difficult to control. Nonetheless, there are several ways of managing the pest reported in other parts of the world that can potentially be adapted and/or validated and used in Ethiopia. Hence, to manage these sporadic pests we have to use different management options. Among those, cultural, chemical, biological and integrated pest management is commonly used in pest infestation. Therefore, this paper initiated with the objective of reviewing the Status of fall armyworm (Spodoptera frugiperda), Biology and control measures on maize in Ethiopia.
\end{abstract}

Keywords: Fall armyworm, current Status, biology, environment, maize, Ethiopia.

\section{INTRODUCTION}

Maize (Zea mays) is one of the main and popular cereal crops due to its high value as stable food as well as its stover demand for animal feed and fuel and even for construction purposes (Abebe and Feyisa, 2017). Maize is also the most important stable crop in terms of calorie intake in Ethiopian rural families. Approximately $88 \%$ of maize produced in Ethiopia is used as food, in both green cobs and grain (Nigussie et al., 2001). Because of its multiple advantages, it ranks second in production area next to teff while it ranks first in its productivity among major cereal crops (Abate et al., 2015) and it is, therefore, one of the high priority crops to feed the everincreasing Ethiopian population (Nigussie et al., 2001). Despite its current productivity is higher than other major cereal crops, the yield productivity is below its

* Corresponding Author:

Email: fentaassefa1@gmail.com

(C) 2018 ESci Journals Publishing. All rights reserved. potential. This is due to many biotic and abiotic factors that can contribute to its yield potential of productivity to be below the previous productivity. In recent years, the country's maize fields have been repeatedly hit by different disasters, including diseases and drought, creating a negative impact on productivity. From the aforementioned factors threaten maize production and productivity in Ethiopia, fall armyworm (Spodoptera frugiperda) is the major one nowadays. The Fall Army Worm (FAW), scientific name Spodoptera frugiperda (J.E. Smith) (Lepidoptera: Noctuidae), is a polyphagous pest that is indigenous throughout the Americas (Commonwealth Institute of Entomology, 1985; Todd and Poole, 1980). It is regularly intercepted in intercontinental trade (CABI, (2017a); Jeger et al., 2017) but has not previously become established outside the Americas. It has now appeared in Africa (Cock et al., 2017; Goergen et al., 2016)) and is rapidly spreading throughout tropical and subtropical regions of the 
continent. It was first detected in Africa in 2016 in Nigeria, Sao Tome and Principe, Benin, and recently Togo. The fall armyworm, which first arrived in Africa in 2016 (Goergen et al., 2016), was intercepted on a few hectares of irrigated maize fields in southern Ethiopia in February 2017and now it has covered about 52, 962 hectares in 144 districts in six of the major maizegrowing regional states, namely Benishangul-Gumuz, Amhara, Tigray, Gambella, Oromia and Southern Nations, Nationalities and Peoples' Region (Tesfaye Getnet, personal communication, October 16, 2017).

The Fall Armyworm is a migratory insect pest known to cause massive destruction of maize crops under warm and humid conditions in the Americans. According to Zebdewos Salato, personal communication, January 30, 2017, Director of the Plant Protection Directorate at the Ethiopian Ministry of Agriculture and Natural Resources in Ethiopia, maize fields planted in Belg and Meher seasons in the prevailing warm and moist weather conditions provide favorable environment for the insect to multiply massively and spread to more areas. This implies that the weather conditions from March to September in maize growing areas provide fertile ground for the insect to mass multiply and spread easily. The fall armyworm of a single generation can spread quickly as far as $500 \mathrm{~km}$ away from its point of emergence aided by wind front (Pogue, 2002). As yet, the literature review undertaken by (CABI, 2017a) has found little evidence regarding what triggers adult dispersal, or indeed whether it is a feature of every generation. Similarly, we have found no studies on whether part of each generation remains in situ, or whether the entire generation disperses. But we have not found any definitive studies on this aspect. It seems likely that dispersal is triggered by the level of crowding experienced by the larvae, but this has not been tested. This makes it difficult to make robust forecasts of the likely pest problem in the next cropping cycle. It has been assumed that FAW disperses on wind-assisted flights until they are sexually mature and ready to mate (Rose et al., 1975). Ethiopia has earned close to half a billion Birr from the export of maize to Kenya, amid rising concern in drought-affected areas and a series of attacks by the fall armyworm across the nation's maize fields (ABDISA, 2017).

BIOLOGY AND DISTRIBUTION OF FALL ARMYWORM

Biology of fall armyworm: FAW, like many others, is polyphagous and can live on over 80 species of crops and weeds (Pogue, 2002), and can move over 300 miles per generation (Ashley et al., 1989). Warm, humid and heavy rainfall favours its reproduction. Fall armyworm is nocturnal and mating occurs during the night. After a pre-oviposition period of three to four days, the female normally deposits most of her eggs during the first four to five days of life, but some oviposition may occur for up to three weeks. Eggs are laid in clusters, mainly on the underside of leaves, covered by dense scales. Like most insects, it has four stages to complete lifecycle (figure 1) hatch in two to four days when the temperature is in the range of 21-27 degree Celsius. The larva has six developmental instars, often the older stages causing higher damage proportioned to over $70 \%$ of the overall damage. A single larva can chew out about $140 \mathrm{~cm} 2$ of maize leaf area to complete the larval development period. Fully developed larvae pupate in soil at a depth of $3-10 \mathrm{~cm}$. When the soil is too hard to penetrate, the larva may pupate above the ground by webbing together leaf debris and other materials to form a cocoon on the soil surface.

Identification of larvae in the field is not straightforward, especially for inexperienced observers, as they are easily confused with similar species such as the African armyworm ( $S$. exempta) and the cotton leafworm $(S$. littoralis), as well as species of other noctuid genera, such as African maize stalk borer (Busseola fusca) or even stem borers of other families, such as the spotted stem borer (Chilo partellus; Crambidae). CABI has prepared guides to assist with diagnosis (CABI, 2017b, 2017c), which are being disseminated through national programs via the Plantwise knowledge bank. Fully developed larvae burrow 2-10 $\mathrm{cm}$ into the soil to pupate; pupation may take from one to five weeks, depending on the soil temperature.

Larvae, especially larger larvae, are cannibalistic, feeding on other $S$. frugiperda larvae, especially smaller ones when they co-occur. Cannibalism was found to account for approximately $40 \%$ mortality when maize plants were infested with two or four fourth-instar larvae over a three-day period (Chapman et al., 2000). This behaviour, which is different from that of African armyworm, is accentuated when food is limited and larvae are crowded (Chapman et al., 2000). The role of this density-dependent mortality in the overall population dynamics is not clear (Chapman et al., 1999) but could be an important point, as density-dependent mortality may reduce the intensity of some outbreaks, 
although clearly, the experience in Africa shows that it does not prevent outbreaks. Dispersal of the newly hatched larvae should minimize cannibalism when Table 1. Stages of fall armyworm.

\begin{tabular}{cccc}
\hline Instar No. & Body length & Colouring & Markings \\
\hline $1 \& 2$ & $1.5-3.5$ & Green with a black head & None \\
\hline $3 \& 4$ & $6-10$ & $\begin{array}{c}\text { Dorsal area tan colour, } \\
\text { ventral area green. Lateral } \\
\text { white/beige stripes visible }\end{array}$ & $\begin{array}{c}\text { Four dark pinacula or raised spots arranged in a square on } \\
\text { the } 8^{\text {th }} \text { abdominal segment and in a trapezoid on the } 9^{\text {th }}\end{array}$ \\
\hline $5 \& 6$ & $15-40$ & Light tan, green, black & $\begin{array}{c}\text { Four dark pinacula or raised spots arranged in a square on } \\
\text { the } 8^{\text {th }} \text { abdominal segment and a trapezoid on the } 9^{\text {th }}\end{array}$ \\
\hline
\end{tabular}

Source: (CABI, 2017b).

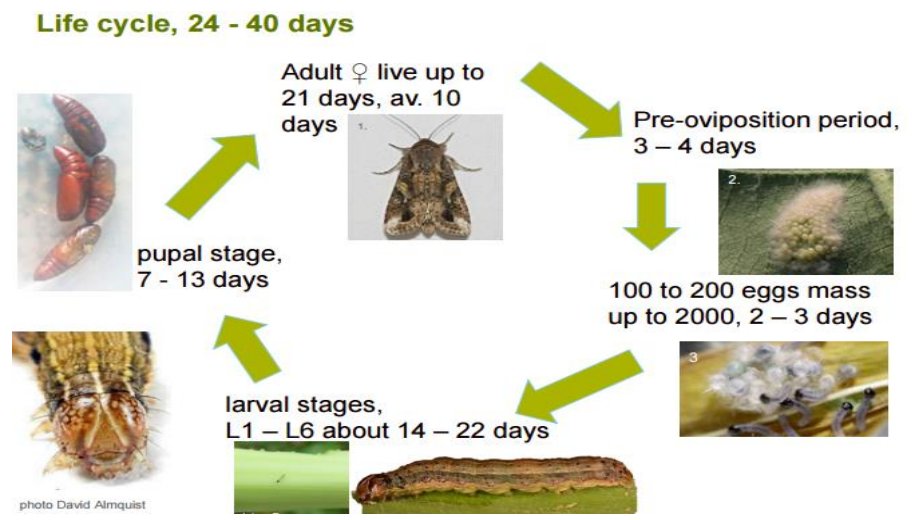

Figure 1. The Lifecycle of Fall Armyworm.

Source: $h t t p: / / w w w . p o t a t o e s . c o . z a / S i t e R e s o u r c e s / d o c u m e n t s / D v H-F A W-J a n-20171 \% 20(5) . p d f$

Distribution of fall armyworm in Ethiopia: Ethiopia was one of the last countries to confirm the presence of FAW; even so, the country has been severely affected by the pest. As of early June, FAW was confirmed in six major maize-producing regions, including the remote, rural areas of the Gamo Gofa Zone where Nuru Ethiopia (NE) operates. FAW is reported to be affecting nearly 150,000 hectares of maize planted across Ethiopia. The 2015/16 El Niño-induced drought left more than 10 million households in Ethiopia in need of food assistance. Farmers were beginning to recover from the drought, but then Maize Lethal Necrosis Disease (MLND) affected the maize crop, and FAW was introduced and reported as a major problem in February 2017. FAW is a tropical species adapted to the warmer climates with temperatures between 10.9- 30 degree Celsius. At lower temperatures, all stages of FAW are killed and at an above temperature ( $>30$ degree Celsius), the wings of the adult FAW tend to be deformed. In much of Ethiopia, the temperature drops twice in a year, during summer (June-August) and winter (October-January). population levels are low. What this also means is that assumptions based on the biology and ecology of African armyworm may not be directly transferable to FAW. the $8^{\text {th }}$ abdominal segment and a trapezoid on the $9^{\text {th }}$ 
342, 708 hectares of maize in Oromia, 133, 705 hectares in the Southern Nations, Nationalities and Peoples' states, 36, 677 hectares in Binishangul Gumuz,122,520 hectares in Amhara and, 5230 hectares in Tigray regions has been affected by the armyworm (Tesfaye Getnet, personal communication, October 16, 2017).

Aided by wind, the fall armyworm of a single generation can rapidly spread over 500 kilometres of space (Ashley, 1979). It has been reported that the pest spread over 46,320 hectares lands in three months' time since its entrance to Ethiopia's southern part through the border of Kenya. Continental research centres and developmental organizations have indicated that fall armyworm has become the worst destructive pest in reducing maize production in Africa. Fall armyworm is such a destructive pest that it feeds in large numbers on the leaves and stems of more than over 100 plant species (Pogue, 2002), including economically important cultivated crops such as maize, millet, wheat, potato, soybean, cowpea, peanuts, sorghum, rice, sugarcane, even vegetables and cotton (CABI, 2017 ; Pogue, 2002).

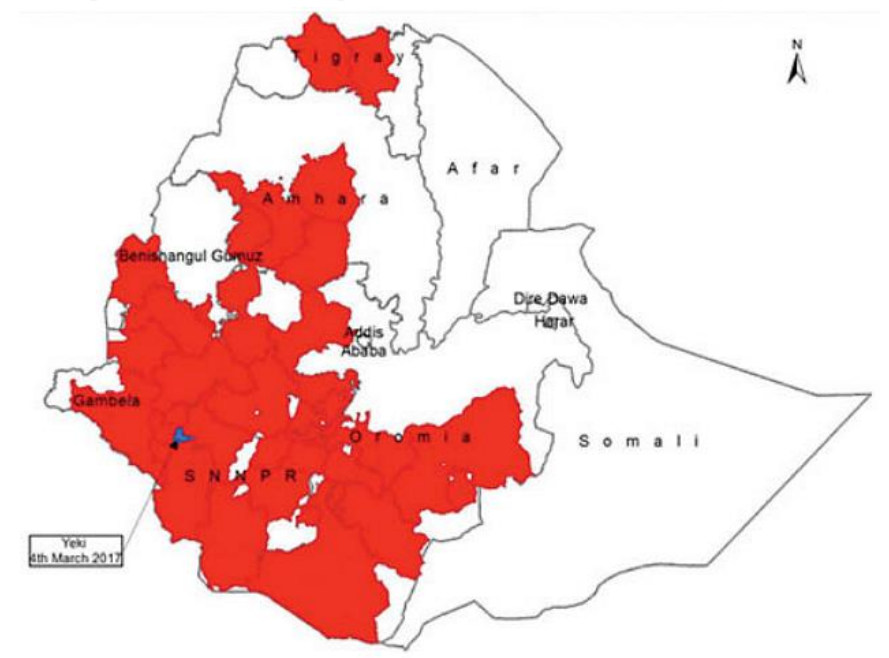

Figure 2. Status of Fall Army Worm in Ethiopia,16 June 2017.

Source: http://www.agri-learning ethiopia.org/wpcontent/uploads/2015/10/AKLDP-Armyworm-brief-online.pdf

Distinguishing features of fall armyworm: FAW, a new devastating insect pest is one of the serious major problems for agricultural crop production especially under poacea family. This is due to;

- The pest: FAW produces several generations per year (is multivoltine), migrates over wide areas, and sometimes is gregarious i.e. live in flocks.

- The host: it is reported that FAW larvae feed on a wide range of plants, as many as 80-186 plant species, of 27 families. The preferred hosts are grassbased plants such as maize, sorghum, millet, rice, and sugarcane. Other hosts include cotton, alfalfa, peanuts, soybeans, cowpeas, tobacco, vegetables, potatoes, and various wild grasses such as Sudan grass. In addition, teff belongs to the grass family and is indigenous to Ethiopia and could be a potential host for FAW.

- The environment/climate: Climatic factors can directly affect the pest and indirectly affect hosts or predators. With climate change, migratory and polyphagous insects (feeding on various kinds of food) like FAW are expected to spread and become established in new areas.

- It is very hungry (and not picky) - This pest targets maize (corn) and other cereal crops, like its African namesake, but it also attacks cotton, soybean, potato and tobacco crops. When it does invade, up to threequarters of the crop can be destroyed.

- Unknown enemy - Governments, communities and farmers have no previous experience of dealing with the new pest, which may be even harder to deal with than its native equivalent.

- Armyworms can destroy entire fields.

- It travels far and wide - The caterpillar stage does the damage, but "it's the adult moth that migrates long distances and that's how it's managed to get around Africa," says Professor Ken Wilson, an expert on armyworms. 
- It is not just targeting any old crop - Maize is the primary food staple in many of the areas where the pest has been identified.

- It is hard to find - The fall armyworm burrows right into the stem of maize plants, concealing it from view and preventing farmers from spotting the problem early.

- Bad timing - It comes after two years of record droughts, which have already affected more than 40 million people in the region, making $15 \%$ less food available, according to the UN.

Damage of Maize crop by Fall Armyworm: Maize became increasingly important for realizing food security in Ethiopia following the major drought and famine that occurred in 1984. Ethiopia has doubled its maize production in less than two decades. The yield, currently estimated is greater than 3 metric tons per hectare, making it the second highest in Sub-Saharan Africa, after South Africa. Yield gains for Ethiopia grew at an annual rate of $68 \mathrm{~kg}$ per hectare between 1990 and 2013, only second to South Africa and greater than
Mexico, China, or India. Approximately $88 \%$ of maize produced in Ethiopia is consumed as food, both as green and dry grain. Maize for industrial use has also shown a growing demand. In recent years, the country's maize fields have been repeatedly hit by different disasters, including diseases and drought, creating a negative impact on productivity. From aforementioned factors threaten maize production and productivity in Ethiopia, fall armyworm (Spodoptera frugiperda) is the major one nowadays. Spodoptera frugiperda causes significant damage to economically important cultivated grasses including maize, rice, sorghum, sugarcane, but also vegetables and cotton. Infestations during the mid-to-late corn stage may result in yield losses of $15-73 \%$ when $55-100 \%$ of the plants are infested (Hruska and Gould, 1997). As shown in (Figure 3), $S$. frugiperda caterpillars appear to be much more damaging to maize in West and Central Africa than most other African Spodoptera species (IITA, 2016).

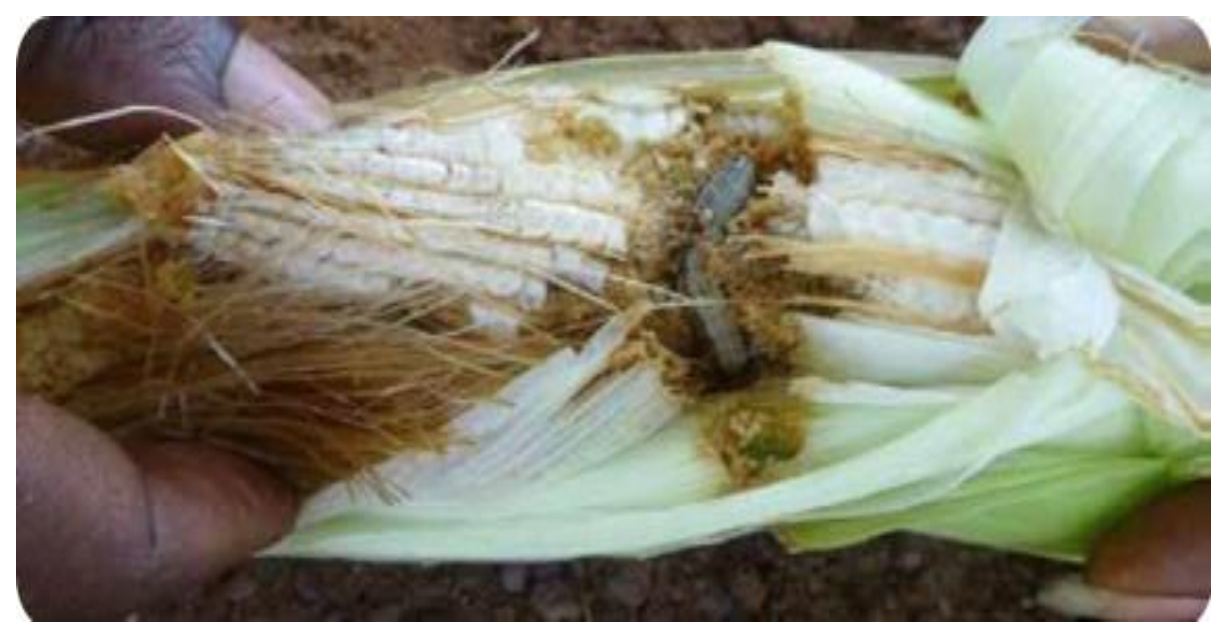

Figure 3. Spodoptera frugiperda caterpillar causing damage on corn cob (Source: CABI, 2017).

According to Roger Day, Coordinator of the Center for Agriculture and Biosciences International (CABI), a conservative estimate indicates that maize losses could amount to US \$ 3 billion for the African continent in the coming year because of the fall armyworm. Maize is the preferred crop for the pest; it also affects other major crops such as sorghum. Fall armyworm (FAW) threatens household food security in the current season and for years to come. If not controlled, FAW can potentially devastate hundreds of thousands of hectares of plants farmland, especially maize. In Ethiopia, FAW mainly affects maize and it is estimated to cause up to $30 \%$ loss unless it is timely controlled (Fentahun Mengestu, Personal Communication, October 26, 2017). Damage to maize may be observed in all plant parts depending on the development stage. Larger caterpillars act as cutworms by entirely sectioning the stem base of maize plantlets. During the maize vegetative phase, constant feeding results in skeletonized leaves and heavily windowed whorls loaded with larval frass. On grown maize plants, larvae also attack reproductive organs feeding on tassels or boring into the ears. Following hatching, neonate larvae usually bore into the host plant and develop under protected conditions. In Ethiopia, 
about nine million smallholder farmers grow maize on 2 million hectares of land, and 75 percent of the maize produced is consumed family as food. A dry stock is mainly used for animal feed and part as fuel and the rest left to decay and amend the soil. Amadou Allahoury, FAO Representative in Ethiopia said, "Millions of Ethiopian farmers rely on maize crop as a staple food. The livelihood of these smallholder farmers will be at stake if the threat of the pest is not foiled. As FAO, we will continue providing the needed support to the Government in its efforts to tackle the problem.

\section{CONTROL MEASURES}

Control Tactics in the world: The literature on this pest is extensive (Ashley et al., 1989). This is in part due to the importance of maize, the importance of lepidopteran pests, the quest for alternative control methods following the development of insect resistance to pesticides, and the development of host-plant resistance breeding programmes. On maize, if $5 \%$ of seedlings are cut or $20 \%$ of whorls of small plants (during the first 30 days) are infested, it is recommended that an insecticide is applied (King \& Saunders, 1984). According to the Ethiopian agricultural ministry, the nature of the insect and its unknown character in the East African country and the region has made the fight against the pest difficult. The management options are cultural, chemical, biological and integrated pest management. The farmers who adopt mechanical method are controlling the pest up to 54\% (Fentahun Mengestu, personal communication, October 26, 2017). The exact timing for applying the listed management options is very important for effective pest elimination; both the life cycle and the time of day for application are very important for successful pest management (e.g. spraying when the larvae is safe inside ears of maize whorls is ineffective and spraying during the day is ineffective because the larvae actively feed only during the night and at dawn or dusk).

Cultural Control: According to Bahiru Setegna, personal communication, June 18, 2017 in Ethiopian Herared local news, yet, a lasting control of armyworm is possible through a combination of cultural and chemical control. The cultural control includes avoiding late planting-for early harvest allows maize ears to escape the higher armyworm invasion that develops later in the season, intercropping of maize with non-host crops like sunflower and bean, and rotating maize cultivation with a non-host. Further, preventing the movement of the pest from infested areas to non-infested areas, removing and destroying all crop residues after harvest, ploughing the soil deeply to expose larvae and pupae to the upper surface of the soil, regularly weeding the field and surroundings, conserving shelters for beneficial insects, and applying optimum fertilizer to improve crop vigour should be practiced. Cultural control such as;

- Early planting to avoid periods of high pest densities.

- Good soil preparation will affect pupae in the soil.

- Crop rotation with non-host plants and varietal choice may well contribute to reducing pest pressure.

- It is advisable to burn stubbles and cuttings after harvesting on infested fields. This will kill both the unhatched eggs, larvae, pupae and adults left on the field at harvest.

- Early \& regular visual inspection is one possibility to detect the pest's presence.

Chemical control: Chemical control involves the application of poisons to the pest and/or crop that kill the FAW through a variety of mechanisms, including on contact or through ingestion. Most commonly, the pesticides are diluted with water and sprayed on growing plants at around 200-400 litres per hectare, though this can vary considerably with the age of the plant and the application method. Seed treatment is reported as effective with thiamethoxam (de Albuquerque, 2006), but Azevedo et al. (2004) found it not to be effective. Several highly or extremely hazardous compounds are effective as seed treatments, but these should not be used. Thrash et al. (2013) reported use of chlorantraniliprole and cyantraniliprole as seed treatments in soya reduced the need for foliar sprays against FAW in soya. In laboratory tests, thiodicarb and clothianidin reduced the number of plants cut or insured by FAW, but chlorpyrifos, fipronil and thiamethoxam were not effective (Camillo et al., 2005). Kerosene is ineffective as a seed treatment (Portillo et al., 1994). Another approach is to apply pesticide to the soil at planting, though this is likely to be less efficient than seed treatments. van Huis (1981) concluded that in experiments in Nicaragua, soil treatment did not exert any control on FAW.

Pesticides applied to the growing crop are most effective when used at the right time and in the correct way. This includes spraying when the larvae are still young; spraying in the early morning, later afternoon or night when the larvae are more active; and directing the spray into the funnel (when using knapsack sprayers) of 
affected plants. It is likely that the many reports from farmers of pesticides "not working" are due to inappropriate application methods or applied when it is too late. Feeding stimulants or attractants mixed with pesticides can increase effectiveness at lower concentrations, although they are not widely used.

Biological control: There are 53 species of parasites, representing 43 genera and 10 families that attack fall armyworm globally (Ashley, 1979; Sparks, 1986) Entomogenous pathogens can suppress fall armyworm populations in at least three ways: These are; optimization of naturally occurring diseases, introduction and colonization of pathogens into insect populations as natural regulatory agents, and repeated applications of pathogens as microbial insecticides (Gardner and Fuxa 1980). Several microbial pathogens have been studied in hopes of utilizing them to control fall armyworm populations. Viruses demonstrate limited efficacy against fall armyworm, but are not temporally effective, allowing for significant damage prior to insect mortality (Sparks, 1986).

Inconsistent results have been documented in field studies evaluating the use of entomogenous pathogens to suppress fall armyworm on corn and cabbage. Fall armyworm-specific Bt isolates have not been developed for commercial spray formulations (Sparks, 1986), but the Cry1F Bt protein is generally considered to be more toxic to fall armyworm than other Cry proteins (Tindall et al., 2006).

Current literature does not describe predators that attack fall armyworm. Many predators attack fall armyworm eggs and larvae. Among the predators noted as important are various ground beetles (Coleoptera: Carabidae); the striped earwig, Labidura riparia (Pallas) (Dermaptera: Labiduridae); the spined soldier bug, Podisus maculiventris (Say) (Hemiptera: Pentatomidae); and the insidious flower bug, Orius insidiosus (Say) (Hemiptera: Anthocoridae). Vertebrates such as birds, skunks, and rodents also consume larvae and pupae readily. Predation may be quite important, as Pair and Gross Jr (1984) demonstrated 60 to 90 percent loss of pupae to predators in Georgia. But there is no summary available to describe these species (Lewis \& Nordlund, 1980; Sparks, 1986). While predators have an effect on fall armyworm survival and development, their role is largely undermined by parasitoids, which are more efficient in affecting fall armyworm populations. Previous attempts to utilize fall armyworm parasitoids generally have been unsuccessful (Gross Jr and Pair, 1986; Sparks, 1986).

Extracts of many plants show insecticidal activity against FAW (Batista-Pereira 2007), but relatively few have been successfully commercialized. Azadirachtin (from neem) and pyrethrins (from pyrethrum) and the most widely found product although in Latin America there are only a handful of registered products. Globally, there are registered products based on rotenone, garlic, nicotine, rianodine, quassia and other extracts (Isman, 1997). The products may be formulated to be diluted with water and sprayed in the same way as chemical pesticides, although dust formulations are also available. One problem with the use of neem on a large scale is the high photosensitivity of azadirachtin, which breaks down or isomerizes under sunlight; thus, neem has a low residual effect under field conditions. Moreover, the lack of standardization and quality control in neem-based formulations produced affect the reproducibility of the insecticide effect (Forim et al., 2010). Viana and Prates (2003), using an aqueous extract from neem leaves at $1 \%$, found that the mortality level of $\mathrm{S}$. frugiperda caterpillars was low during the first three days, after initial feeding, and high by 10 days, indicating that protocols for testing the efficacy of conventional pesticides may not be suitable for testing neem extracts.

FAW management options in Ethiopia: At present, the major problems affecting FAW management efforts in Ethiopia are:

- Lack of adequate knowledge of the pest and its management options in the Ethiopian context.

- Lack of sound contingency and long-term plans.

- Lack of coordinated research and development interventions.

- The scarcity of financial and material resources.

- Delayed response.

FAW's ability to breed rapidly, to migrate, and to feed on a wide range of host plants makes it is very difficult to control. Nonetheless, there are several ways of managing the pest reported in other parts of the world that can potentially be adapted and/or validated and used in Ethiopia (Table 2). 
Table 2. FAW management options in Ethiopia.

\begin{tabular}{|c|c|c|}
\hline FAW management options & Limitations/setbacks & Recommendations \\
\hline \multicolumn{3}{|l|}{ Cultural option } \\
\hline $\begin{array}{l}\text { - Diagnosis and monitoring } \\
\text { - (and scouting approaches) } \\
\text { - Phytosanitary measures } \\
\text { (disking or deep plowing) } \\
\text { - Planting date adjustment } \\
\text { (synchronized early planting) } \\
\text { - Mechanical control (hand } \\
\text { picking and squashing of } \\
\text { caterpillars) }\end{array}$ & $\begin{array}{l}\text { - Farmers' inability to properly } \\
\text { scout and detect the early instars } \\
\text { and take the necessary control } \\
\text { measures in time } \\
\text { - Unsynchronized planting due to } \\
\text { farmers varying plans, lack of } \\
\text { resources such as oxen, lack of } \\
\text { understanding } \\
\text { - Reluctance to kill the larvae } \\
\text { because of disgust and the } \\
\text { speculative belief that the } \\
\text { population builds up as larvae } \\
\text { are killed }\end{array}$ & $\begin{array}{l}\text { - Use of pheromone/light traps; frequent } \\
\text { field inspection and monitoring } \\
\text { - Clean cultivation and weeding } \\
\text { - Use of early maturing varieties, early } \\
\text { planting, intercropping, and crop } \\
\text { rotation with a non-host crop } \\
\text { - Bird combing of the pupae and larvae } \\
\text { from the soil } \\
\text { - Livestock grazing on infested pastures } \\
\text { - Developing tools for crushing the larvae }\end{array}$ \\
\hline \multicolumn{3}{|l|}{ Chemical option } \\
\hline $\begin{array}{l}\text { - Insecticide application } \\
\text { - (pyrethroids, carbamates, and } \\
\text { - organophosphates category) }\end{array}$ & $\begin{array}{l}\text { - Chemicals in use are general } \\
\text { purpose ones; no specific } \\
\text { chemical recommended for FAW } \\
\text { - The potential for resistance } \\
\text { development from inappropriate } \\
\text { use of pesticides } \\
\text { - No pest threshold level on } \\
\text { issuing chemical options } \\
\text { - Improper timing and application } \\
\text { of pesticides, leading to } \\
\text { ineffective control, significant } \\
\text { human health } \\
\text { - problems, livestock poisoning, } \\
\text { plant damage, environmental } \\
\text { pollution, high expenditures }\end{array}$ & $\begin{array}{l}\text { - Urgent need for fast-track testing and } \\
\text { identification of soft pesticides targeting } \\
\text { FAW and if need be emergency } \\
\text { - registration and recommendation of } \\
\text { more efficient pesticides } \\
\text { - Chemical control options should be } \\
\text { based on threshold-level determination } \\
\text { - Schedule safe chemical sprays matching } \\
\text { the pest's active feeding time at twilight, } \\
\text { - and proper guidance to be given } \\
\text { concerning chemical application } \\
\text { (dosage, protective equipment, etc.) } \\
\text { - Use of spray windows, swath } \\
\text { application, alternating different mode- } \\
\text { of-action insecticides, etc. }\end{array}$ \\
\hline \multicolumn{3}{|l|}{ Biological option } \\
\hline $\begin{array}{l}\text { Botanicals like Neem, } \\
\text { Thephrosia, Tagetes, } \\
\text { Chrysanthemum } \\
\text { - Classic biological control, } \\
\text { especially parasitoid } \\
\text { (Telenomus remus) } \\
\text { - Bio-pesticides } \\
\end{array}$ & $\begin{array}{l}\text { - Lack of rapid efficacy } \\
\text { - Risk of attacking non-targets } \\
\text { - May take a long time to control }\end{array}$ & $\begin{array}{l}\text { - Use botanicals as part of integrated pest } \\
\text { management (IPM) } \\
\text { - Rapid efficacy testing, and risk analysis } \\
\text { needed }\end{array}$ \\
\hline \multicolumn{3}{|l|}{ Integrated pest management } \\
\hline $\begin{array}{l}\text { - Combined use of all available } \\
\text { pest management options }\end{array}$ & $\begin{array}{l}\text { Farmer's inclination towards } \\
\text { chemical control as a first choice }\end{array}$ & $\begin{array}{l}\text { Use a combination of pheromone traps, } \\
\text { cultural, mechanical, and biological } \\
\text { options, and host plant resistance (if } \\
\text { found) } \\
\text { - Integrate affordable soft chemicals as a } \\
\text { last resort }\end{array}$ \\
\hline
\end{tabular}


Table 2. suggests that all options have their advantages and disadvantages. Therefore, a judicious combination of different options, including cultural, chemical, and biological ones, i.e., integrated pest management (IPM), needs to be considered. This helps to minimize the use of insecticides and tackle resistance development challenges, while it reduces socioeconomic and environmental impacts. Most importantly, maize is a cheaper-priced commodity in Ethiopia, so only reduced use of an efficient application of chemicals is economically viable.

\section{CONCLUSION}

Ethiopia was one of the last countries to confirm the presence of FAW in East Africa. FAW is a tropical species adapted to the warmer climates with temperatures between $10.9^{\circ} \mathrm{C}$ to $30^{\circ} \mathrm{C}$. At lower temperatures, all stages of FAW are killed. Above $30^{\circ} \mathrm{C}$, the wings of the adult FAW tend to be deformed. In much of Ethiopia, the temperature drops twice in a year, during summer (June-August) and winter (October-January). The 2015/16 El Niño-in Ethiopia increase the temperature and change the climate of the country. Consequently, it induces severe drought in 2015/17 and makes the environment for the introduction of FAW to Ethiopia. The entire life of fall armyworm is completed in 30 days during warm weather and it can take up to 90 days during cool weather. Eggs are usually laid on the underside of leaves. Total egg production per female averages about 1500 with a maximum of over 2000 . Fall armyworm pest can travel up to five $\mathrm{km}$ with the help of wind. Due to these conditions, the pest is found on maize farms in 235 woredas in 35 Zones of Ethiopia. Fall armyworm is such a destructive pest that it feeds in large numbers on the leaves and stems of more than over 100 plant species, including economically important cultivated crops such as maize, millet, wheat, potato, soybean, cowpea, peanuts, sorghum, rice, sugarcane, even vegetables and cotton. But, In Ethiopia, FAW mainly affects maize and it is estimated to cause up to $30 \%$ loss unless it is timely controlled which is important for realizing food security.

FAW, a new devastating insect pest is one of the serious major problems for agricultural crop production especially under poacea family in Ethiopia. This is due to;

- It travels far and wide.

- An unknown enemy.

- It is hard to find.
- Bad timing.

- Multivoltine and.

- FAW's ability to breed rapidly, to migrate, and to feed on a wide range of host plants makes it is very difficult to control.

Nonetheless, there are several ways of managing the pest reported in other parts of the world that can potentially be adapted and/or validated and used in Ethiopia. Hence, to manage these sporadic pests we have to use different management options. Among those, cultural, chemical, biological and integrated pest management are commonly used in pest infestation. The farmers who adopt mechanical method are controlling the pest up to $54 \%$. The exact timing for applying the listed management options is very important for effective pest elimination; both the life cycle and the time of day for application are very important for successful pest management (e.g. Spraying when the larvae are safe inside ears of maize whorls is ineffective and spraying during the day is ineffective because the larvae actively feed only during the night and at dawn or dusk).

\section{FUTURE LINE OF WORK}

As the fall Armyworm is a new devastating pest in Ethiopia, there are no experiences about its biology, ecology, production, dispersal mechanisms and preventive management options before it comes into contact our field. Hence, it is better to;

- Conduct research on its management options in Ethiopia.

- Take Quarantine measures on its all border of Ethiopia.

- Identify all its life cycle under laboratory and time take for every six instars.

- Examine its ability of fecundity/production in different Ethiopian AEZs.

- Create awareness about the pest and its management options in the Ethiopian context.

- Have an alarming response upon its occurrence due to its ability to breed rapidly, to migrate, and to feed on a wide range of host plants.

- Promote awareness of FAW, its identification, damage and control in consultation with agro-input suppliers and government agents.

- Prepare and communicate lists of recommended pesticides for control.

- Develop and implement FAW Damage Assessment materials to improve real-time monitoring of the 
severity and extent of FAW damage to farmer fields.

- Procure and distribute pesticides, where needed, through farmer-led cooperatives to ensure timely access to chemical control in 2017.

- Provide Health and Safety materials and training to all farmers handling or spraying chemical pesticides with Nuru assistance.

- Research into companion/decoy plants that can be used to attract FAWs away from damaging economically significant crops, like maize.

\section{REFERENCES}

Abate, T., B. Shiferaw, A. Menkir, D. Wegary, Y. Kebede, K. Tesfaye, M. Kassie, G. Bogale, B. Tadesse and T. Keno. 2015. Factors that transformed maize productivity in Ethiopia. Food Security. 7(5): 965981.

Abdisa, H. 2017. Maize Export Surges Amid Uncertainty. FORTUNE. 18(896).

Abebe, Z. and H. Feyisa. 2017. Effects of nitrogen rates and time of application on yield of maize: rainfall variability influenced time of $\mathrm{N}$ application. International Journal of Agronomy. 2017.

Ashley, T.R. 1979. Classification and distribution of fall armyworm parasites. Florida Entomologist. 114123.

Ashley, T.R, B.R. Wiseman, F.M. Davis and K.L. Andrews. 1989. The fall armyworm: a bibliography. Florida Entomologist. 152-202.

Azevedo, R de., A.D. Grutzmacher, A.E. Loeck, F.F. da Silva, G. Storch and M.I. Herpich. 2004. Effect of seed treatment and leaf spray of insecticides in different water volumes, on the control of Spodoptera frugiperda (JE Smith, 1797). (Lepidoptera: Noctuidae), in lowland corn and sorghum crops. Revista Brasileira de Agrociencia (Brazil).

CABI. 2017a. Datasheet. Spodoptera frugiperda (fall armyworm). Invasive Species. Compendium http://www.cabi.org/isc/datasheet/29810 [Accessed August 2017].

CABI. 2017b. How to identify fall armyworm. A4 flyer. Plantwise,

http://www.plantwise.org/FullTextPDF/2017/20 177800462.pdf [Accessed August 2017].

CABI. 2017c. How to identify fall armyworm. Poster. Plantwise, http://www.plantwise.org/FullTextPDF/2017/20 177800461.pdf [Accessed August 2017].
CABI. 2017. Spodoptera frugiperda (fall armyworm). Invasive Species Compendium. http://www.cabi. org/isc/datasheet/29810.

CABI. 2017a. Spodoptera frugiperda (fall army worm). Invasive Species Compendium http://www.cabi. org/isc/datasheet/29810.

Camillo, M.F., J.R.G. Oliveira di, A.de.F. Bueno and R.C.O.de.F. Bueno. 2005. Seeds treatment on maize for Spodoptera frugiperda control. Ecossistema. 30(2): 59-63.

Chapman, J.W., T. Williams, A. Escribano, P. Caballero, R.D. Cave and D. Goulson. 1999. Age-related cannibalism and horizontal transmission of a nuclear polyhedrosis virus in larval Spodoptera frugiperda. Ecological Entomology. 24(3): 268-275.

Chapman, J.W., T. Williams, A.M. Martínez, J. Cisneros, P. Caballero, R.D. Cave and D. Goulson. 2000. Does cannibalism in Spodoptera frugiperda (Lepidoptera: Noctuidae) reduce the risk of predation? Behavioural Ecology and Sociobiology. 48(4): 321-327.

Cock, M.J., P.K. Beseh, A.G. Buddie, G. Cafá and J. Crozier. 2017. Molecular methods to detect Spodoptera frugiperda in Ghana, and implications for monitoring the spread of invasive species in developing countries. Scientific Reports. 7(1): 4103.

de Albuquerque, F.A. 2006. Efficiency of insecticides applied in seed treatment and pulverization, in the control of corn initial pests. Revista Brasileira de Milho e Sorgo (Brazil).

Entomology, Commonwealth Institute. 1985. Spodoptera frugiperda. Distr. Maps Plant Pests. 68(revised), 2.

Forim, M.R., A.P. Matos, M.F.D.G.F. Silva, Q.B. Cass, P.C. Vieira and J.B. Fernandes. 2010. The use of HPLC in the control of neem commercial products quality: reproduction of the insecticide action. Quimica Nova. 33(5): 1082-1087.

Goergen, G., P.L. Kumar, S.B. Sankung, A. Togola and M. Tamò. 2016. First report of outbreaks of the fall armyworm Spodoptera frugiperda (JE Smith) (Lepidoptera, Noctuidae), a new alien invasive pest in West and Central Africa. PloS one, 11(10), p.e0165632.

Gross Jr, H.R. and S.D. Pair. 1986. The fall armyworm: status and expectations of biological control with parasitoids and predators. Florida Entomologist, 502-515.

IITA. 2016. First report of outbreaks of the "Fall 
Armyworm" on the African. continent. bulletin no. 2330.

http://bulletin.iita.org/index.php/2016/06/18/fi rst-reportof-outbreaks-of-the-fall-armyworm-onthe-african-continent/Accessed on 17/12/2016.

Isman, M.B. 1997. Neem and other botanical insecticides: barriers to commercialization. Phytoparasitica. 25(4): 339-344.

Jeger, M., C. Bragard, D. Caffier, K. Dehnen-Schmutz, G. Gilioli, J.C. Gregoire, J. Miret, J. Anton, A. MacLeod, M.N. Navarro, and B. Niere. 2017. Pest categorisation of Citrus leprosis viruses. EFSA Journal. 15(12).

King, A.B.S. and J.L. Saunders. 1984. The invertebrate pests of annual food crops in Central America: A guide to their recognition and control: Bib. Orton IICA/CATIE.

Lewis, W.J. and D.A. Nordlund. 1980. Employment of parasitoids and predators for fall armyworm control. Florida Entomologist. 433-438.

Nigussie, M.T.D and S. Twumasi-Afriyie. 2001. Enhancing the contribution of maize to food security in Ethiopia. Paper presented at the Proceedings of the Second National Maize Workshop of Ethiopia.

Pair, S.D. and J.H.R. Gross. 1984. Field mortality of pupae of the fall armyworm, Spodoptera frugiperda (JE Smith), by predators and a newly discovered parasitoid, Diapetimorpha introita. Journal of the Georgia Entomological Society.

Pogue, M.G. 2002. A world revision of the genus Spodoptera Guenée: (Lepidoptera: Noctuidae): American Entomological Society Philadelphia.

Portillo, H.E., H.N. Pitre, D.H. Meckenstock and F. Gómez.
1994. Improved chemical protection of sorghum seed and seedlings from insect pests in Honduras. Turrialba (IICA) v. 44 (1): 50-55.

Rose, A.H., R.H. Silversides and O.H. Lindquist. 1975. Migration flight by an aphid, Rhopalosiphum maidis (Hemiptera: Aphididae), and a noctuid, Spodoptera frugiperda (Lepidoptera: Noctuidae). The Canadian Entomologist. 107(6): 567-576.

Sparks, A.N. 1986. Fall armyworm (Lepidoptera: Noctuidae): potential for area-wide management. Florida Entomologist. 603-614.

Thrash, B., J.J.J. Adamczyk, G. Lorenz, A.W. Scott, J.S. Armstrong, R. Pfannenstiel and N. Taillon, 2013. Laboratory evaluations of lepidopteran-active soybean seed treatments on survivorship of fall armyworm (Lepidoptera: Noctuidae) larvae. Florida Entomologist. 96(3): 724-728.

Tindall, K.V., B.R. Leonard and K.D. Emfinger. (2006). Fall armyworm survivorship and damage in WideStrike cotton. Paper presented at the Proceedings, 2006. Beltwide Cotton Conferences.

Todd, E.L. and R.W. Poole, 1980. Keys and illustrations for the armyworm moths of the noctuid genus Spodoptera Guenée from the Western Hemisphere. Annals of the Entomological Society of America. 73(6): 722-738.

van Huis, A. 1981. Integrated pest management in the small farmer's maize crop in Nicaragua. [sn].

Viana, P.A. and H.T. Prates. 2003. Desenvolvimento e mortalidade larval de Spodoptera frugiperda em folhas de milho tratadas com extrato aquoso de folhas de Azadirachta indica. Bragantia. 62(1): 69-74. 